\title{
AKTUALISASI NILAI-NILAI AL-QUR'AN DI ERA MODERN
}

\author{
Rusydi AM \\ UIN Imam Bonjol Padang \\ Rusydiam@uinib.ac.id \\ التجريد. القرآن كلام الله المنزل علي رسوله محمد صلى الله عليه وسلّم هدى للناس أجمعين

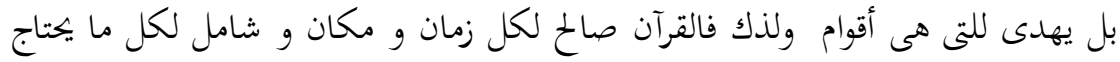

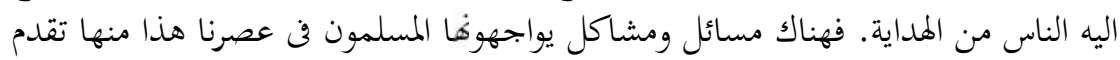

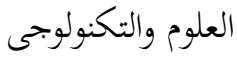 \\ المفردات : القرآن، العلوم والتكنولوجى، المسائل العصرية

\begin{abstract}
Abstrak. Aktualisasi Nilai-nilai al-Qur'an di Era Modern. Al-Qur'an merupakan Kalam Allah yang diturunkan kepada Rasulnya Muhammad Saw. Sebagai petunjuk bagi seluruh manusia bahkan menjadi petunjuk bagi seluruh bangsa. Oleh karena itu maka al-Qur'an sesuai/aktual pada setiap waktu dan tempat, dan mencakup setiap pedoman yang dibutuhkan manusia. Termasuk persoalan-persoalan dan permasalan-permasalah yang berhubungan dengan Ilmu dan Teknologi yang dihadapi oleh kaum muslimin pada era modern.
\end{abstract}

Kata Kunci : al-Qur'an, ilmu dan Teknologi, Persoalan Kontemporer.

\section{AL-QUR'AN UNIVERSAL DAN KOMPREHENSIF}

Al-Qur' an adalah untuk seluruh umat manusia, sebagaimana ditegaskan Allah :

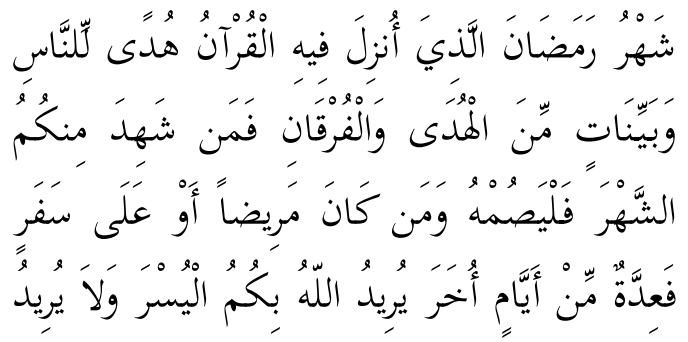

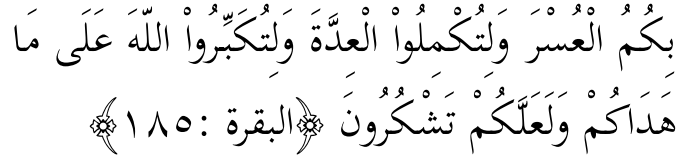

Beberapa hari yang ditentukan itu ialah) bulan Ramadhan, bulan yang di dalamnya diturunkan (permulaan) $A l$ Qur'an sebagai petunjuk bagi manusia dan penjelasan-penjelasan mengenai petunjuk itu dan pembeda (antara yang hak dan yang bathil). Karena itu, barangsiapa di antara kamu hadir (di negeri tempat tinggalnya) di bulan itu, maka hendaklah ia berpuasa pada bulan itu, dan barangsiapa sakit atau 
dalam perjalanan (lalu ia berbuka), maka (wajiblah baginya berpuasa), sebanyak hari yang ditinggalkannya itu, pada hari-hari yang lain. Allah menghendaki kemudahan bagimu, dan tidak menghendaki kesukaran bagimu. Dan hendaklah kamu mencukupkan bilangannya dan hendaklah kamu mengagungkan Allah atas petunjukNya yang diberikan kepadamu, supaya kamu bersyukur. (Q.S. al-Baqarah (2): 185)

Ayat ini sesuai dengan tugas Rasulullah Saw. untuk seluruh umat manusia :

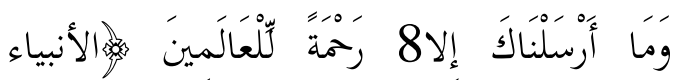

$$
\text { (. v: }
$$

Dan tiadalah Kami mengutus kamu, melainkan untuk (menjadi) rahmat bagi semesta alam. (Q.S. al-Anbiya' (21): 107

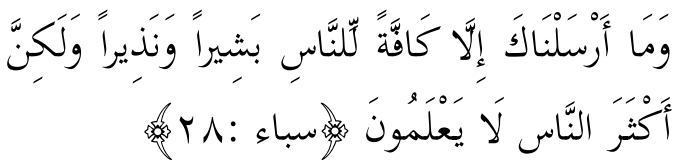

Dan Kami tidak mengutus kamu, melainkan kepada umat manusia seluruhnya sebagai pembawa berita gembira dan sebagai pemberi peringatan, tetapi kebanyakan manusia tiada mengetahui. (Q.S. Saba' (34):28

Oleh karena al-Qur'an untuk se;luruh umat manusia sebagai rahmat, maka kandungannya mencakup segala sesuatu, namun secara global, tidak rinci, sebagaimana firman Allah Swt. :

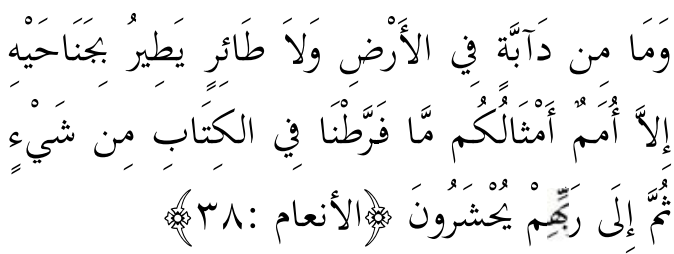

Dan tiadalah binatang-binatang yang ada di bumi dan burung-burung yang terbang dengan kedua sayapnya, melainkan umat-umat (juga) seperti kamu. Tiadalah Kami alpakan sesuatupun di dalam Al Kitab, kemudian kepada Tuhanlah mereka dihimpunkan. (Q.S. al-An'am (6): 38

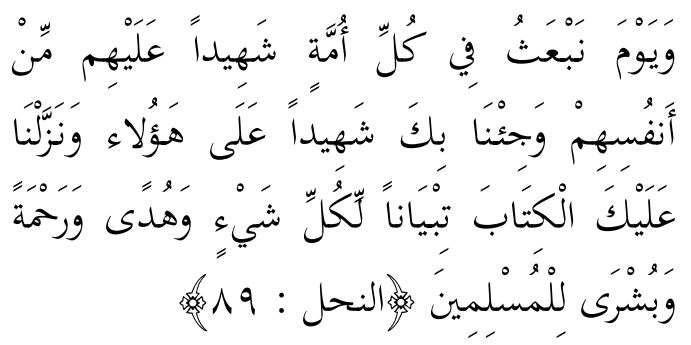

(Dan ingatlah) akan hari (ketika) Kami, bangkitkan pada tiap-tiap umat seorang saksi atas mereka dari mereka sendiri, dan Kami datangkan kamu (Muhammad) menjadi saksi atas seluruh umat manusia. Dan Kami turunkan kepadamu Al Kitab (Al Qur'an) untuk menjelaskan segala sesuatu dan petunjuk serta rahmat dan kabar gembira bagi orang-orang yang berserah diri. (Q.S. Al-Nahl (16), 89

Kemujmalan al-Qur'an sebagai isyarat keuniversalan dan dasar bagi elastisitasnya, memberi peluang kepada mufassir untuk menafsirkan alQur'an, baik secara tekstual, maupun kontekstual. Oleh karena itu, muncullah kreasi-kreasi mufassir yang beraneka ragam atau bervariasi. Ditinjau dari segi metode penafsirannya, lahir tafsir ijmali, tahlili, muqaran dan mawdhu'i. Dilihat dari latar belakang disiplin ilmu dari mufassir, lahirlah berbagai corak tafsir, seperti tafsir falsafi, tafsir fiqhi, tafsir shufi, tafsir ilmi, dan adabi ijtima'i. Sementara bila dilihat dari segi sumber penafsiran, maka tafsir dapat dikelompokkan kepada dua macam, yaitu tafsir bi al- ma'tsur dan 
tafsir bi al-ra'yi. Selanjutnya ditinjau dari segi masa munculnya, ada yang digolongkan tafsir klasik, moderen, dan kontemporer.

\section{AKTUALISASI NILAI-NILAI AL- QUR'AN}

\section{Kemajuan Ilmu Pengetahuan dan Teknologi}

Sebelum membahas manhaj pemahaman dan penafsiran al-Qur'an , ada baiknya terlebih dahulu dikemukakan pengertian tafsir itu sendiri, yaitu :

علم يفهم به كتاب الله المنزل على نبيه محمد

صلى الله عليه وسلم وبيان معانيه و استخراج احكامه وحكمه 1

Suatu disiplin ilmu untuk memahami kitabullah yang diturunkan kepada Nabi-Nya Muhammad Saw., menjelaskan makna-maknanya serta mengeluarkan hukum-hukum dan hikmahhikmah yang terkandung di dalamnya.

Sebagai sumber informasi, alQur'an mengajarkan banyak hal kepada manusia; mulai dari persoalan keyakinan, moral, prinsip-prinsip ibadah dan mu'amalah sampai kepada asas-asas ilmu pengetahuan. Lalu, pertanyaan yang muncul adalah, bagaimana umat Islam dapat memahami al-Qur'an? Selanjutnya. mampukah alQur'an menjawab tuntutan dan tantangan yang timbul dalam masyarakat sejalan dengan kemajuan ilmu pengetahuan dan teknologi ?

Jawabannya adalah bahwa untuk memahami, menggali hukum

${ }^{1}$ Badr al-Din Muhammad bin Abdullah al- Zarkasyi, al-B urhân F i 'Ulûm al-Qur'ân, ( Beirut: Dar al-Fikr, t.th), Juz. I, h. 169 dan hikmah yang terkandung dalam alQur'an tentu harus ada alat yang dipakai. Sebagai pegangan dan petunjuk bagi umat Islam dalam kehidupan, al-Qur'an tentu mampu menjawab tantangan zaman sebagai dampak dari kemajuan ilmu pengetahuan dan teknologi tersebut. Dilihat dari kandungannya, al-Qur'an berisi semua hal yang dibutuhkan oleh manusia, namun al-Qur'an mengemukakan segala sesuatu secara global, bukan secara rinci.

Oleh karena keglobalan alQur'an, ditambah dengan perbedaan dan perkembangan situasi dan kondisi seperti tersebut di atas, maka alQur'an perlu ditafsirkan. Untuk menafsirkan al-Qur'an diperlukan beberapa ilmu bantu, antara lain 'Ulum alQur'an. $^{2}$ Ilmu ini sampai kini tetap dipelajari sebagai alat untuk memahami dan menafsirkan dengan tepat serta menggali kandungan dan pesan al-Qur'an. Ulum al-Qur'an -sebagaimana halnya sebuah disiplin ilmujuga berkembang pesat dari satu generasi ke generasi berikutnya.

'Ulum al-Qur'an berasal dari kata 'ulum ( jama' dari 'ilm )yang berarti kumpulan ilmu dan al-Qur'an, atau kumpulan sejumlah ilmu yang berhubungan dengan al-Qur'an ( $\boldsymbol{a l}$ 'ulûm 'an ahwâl al-Qur'ân ). Dalam memberikan pengertian terminologis dari 'Ulum al-Qur'an ini, pada umumnya ulama menemukan kesepakatan pada dua hal. Pertama, Ulum alQur'an adalah sejumlah ilmu pengetahuan yang membahas tentang alQur'an. Kedua, membuka peluang

2 Ilmu-ilmu yang dibutuhkan untuk menfasirkan al-Qur'an antara lain Bahasa Arab, Hadis, Ushul Fiqh, Ulum al-Qur'an dan lain-lain. 
kemungkinan masuknya aspek lain ke dalam pembahasan 'Ulum al-Qur'an, dengan pengertian bahwa tidak adanya jumlah yang pasti tentang jumlah ilmuilmu yang masuk dalam kategori 'Ulum al-Qur'an. Dengan demikian dapat dikatakan bahwa 'Ulum alQur'an itu sangat dinamis, tidak statis. Hal itu juga berarti bahwa terbuka ruang gerak yang luas bagi pengembangan ilmu tafsir, khususnya mengenai metode penafsiran, misalnya. Metode penafsiran bisa saja berkembang sesuai dengan format masing-masing, namun demikian, perlu digarisbawahi bahwa proses itu tidak menafikan secara kontekstual makna pesan yang terkandung dalam al-Qur'an. Interpretasi bisa berbeda, namun substansi dari kandungan yang sebenarnya tidak boleh menyimpang dari orisinalitas kesuciannya.

Dalam kajian Ulum al-Qur'an ada satu aspek pembahasan yang disebut dengan I'jâz al-Qur'an, yaitu melemahkan (menampakkan kelemahan) bangsa Arab dan non Arab untuk menandingi al-Qur'an, walaupun Allah telah mengemukakan tantangan kepada mereka untuk menulis karya yang setara dengan al-Qur'an. Tantangan alQur'an itu malah bertingkat, yaitu diawali dengan menandingi seluruh alQur'an, kemudian karena mereka tidak mampu, tantangan diturunkan menjadi sepuluh surat saja, bahkan terakhir, diturunkan lagi, yaitu membuat karya tulis yang setara dengan satu surat saja dari al-Qur'an. Namun, seperti yang diinformasikan al-Qur'an sendiri dan sesuai fakta dan realitas, manusia belum mampu dan tidak akan pernah mampu untuk itu (Q.S. 2 : 23-24). Salah satu aspek I'jâz al-Qur'an itu adalah $\boldsymbol{a l}$-I'jâz al-'Ilmi (kemukjizatan ilmiah al-Qur'an).
Al-Qur'an memuat isyaratisyarat ilmiah yang cukup komprehensif dalam berbagai cabang dan disiplin ilmu pengetahuan, baik ilmuilmu pengetahuan sosial, maupun ilmu pengetahuan alam. Semuanya itu menunjukkan keberadaan al-Qur'an sebagai mukjizat terbesar dan di sisi lain membuktikan eksistensinya sebagai sumber ilmu pengetahuan (mashdar al-'ulûm/recourses of knowledge and science), walaupun sewaktu al-Qur'an diturunkan, zaman masih jauh dari kemajuan ilmu pengetahuan. Oleh karena itu, tidak mengherankan bilamana isyarat-isyarat ilmiah al-Qur'an itu belum diungkap oleh kaum Muslimin kala itu. Baru pada masa berikutnya kaum Muslimin berusaha untuk menemukannya, bahkan pada zaman akhir-akhir ini sudah banyak isyarat-isyarat ilmiah yang terdapat dalam al-Qur'an yang telah terbukti kebenarannya oleh para ilmuan.

Sebagai contoh adalah pada mulanya orang berkeyakinan bahwa perkawinan itu hanya berlangsung pada dua jenis, yaitu manusia dan hewan. Ternyata kemudian, ilmu pengetahuan moderen telah menemukan teori bahwa perkawinan juga terjadi pada tumbuhtumbuhan. Perkawinan pada tumbuhtumbuhan itu ada yang zati dan ada yang khalti, maksudnya ada tumbuhtumbuhan yang bunganya telah mengandung organ jantan dan betina dan ada pula tumbuh-tumbuhan yang organ jantannya terpisah dari organ betinanya seperti pohon korma, sehingga perkawinannya melalui perpindahan, dimana sarananya antara lain angin. Apa yang ditemukan oleh ilmuan kontemporer ini telah diungkap al-Qur'an dalam surat al-Hijr (15) ayat 22 : 


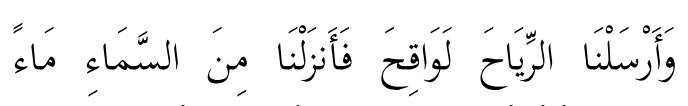

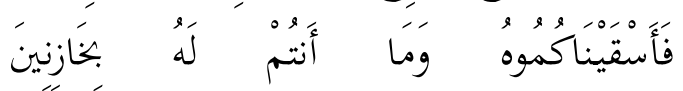

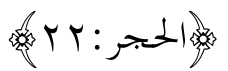

Dan Kami telah meniupkan angin untuk mengawinkan (tumbuhtumbuhan) dan Kami turunkan air hujan dari langit, lalu Kami beri minum kamu dengan air itu, dan sekali-kali bukanlah kamu yang menyimpannya

Al-Qur'an juga berbicara panjang lebar tentang manusia. Salah satu yang dibahasnya adalah tentang embriologi serta tahapan-tahapannya hingga terciptanya seorang manusia. Hal itu dapat dilihat dalam surat alThariq (86) ayat 5-7 :

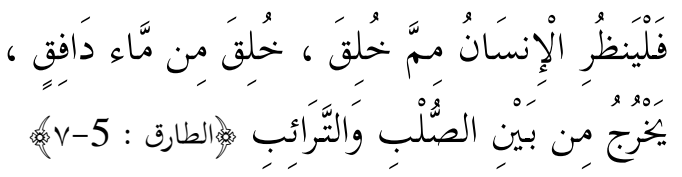

Maka hendaklah manusia memperhatikan dari apa dia diciptakan. Dia diciptakan dari air (mani) yang terpancar, yang keluar dari antara tulang punggung (sulbi) dan tulang dada). ayat 5. :

Selanjutnya surat al-Hajj (22)

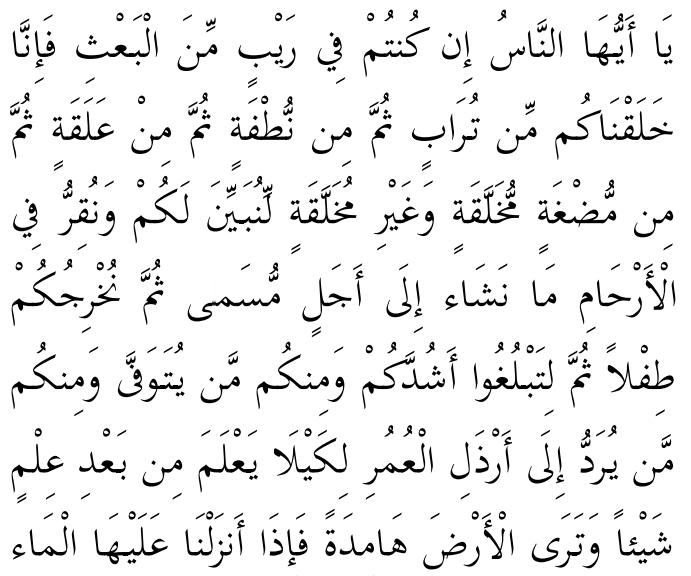

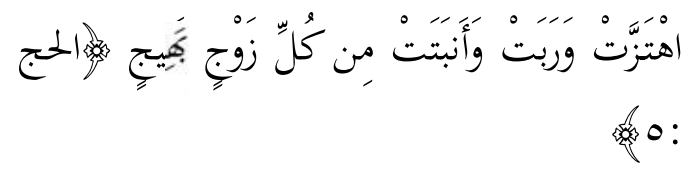

Hai manusia, jika kamu dalam keraguan tentang kebangkitan (dari kubur), maka (ketahuilah) sesungguhnya Kami telah menjadikan kamu dari tanah, kemudian dari setetes mani, kemudian dari segumpal darah, kemudian dari segumpal daging yang sempurna kejadiannya dan yang tidak sempurna, agar Kami jelaskan kepada kamu dan Kami tetapkan dalam rahim, apa yang Kami kehendaki sampai waktu yang sudah ditentukan, kemudian Kami keluarkan kamu sebagai bayi, kemudian (dengan berangsur-angsur) kamu sampailah kepada kedewasaan, dan di antara kamu ada yang diwafatkan dan (ada pula) di antara kamu yang dipanjangkan umurnya sampai pikun, supaya dia tidak mengetahui lagi sesuatupun yang dahulunya telah diketahuinya. Dan kamu lihat bumi ini kering, kemudian apabila telah Kami turunkan air di atasnya, hiduplah bumi itu dan suburlah dan menumbuhkan berbagai macam tumbuh-tumbuhan yang indah.

Dalam hal ini, informasi alQur'an tersebut sejalan dengan penemuan ilmiah yang mengatakan bahwa pancaran mani dari suami ketika berhubungan dengan isterinya mengandung dua ratus juta benih manusia, sedangkan yang berhasil bertemu dengan ovum hanya satu. Itulah yang dimaksud al-Qur'an dengan "nuthfah dari mani yang terpancar".

Selanjutnya, al-Qur'an juga berbicara tentang pentingnya oksigen 
untuk pernafasan manusia seperti diungkap surat al-An'am: 125:

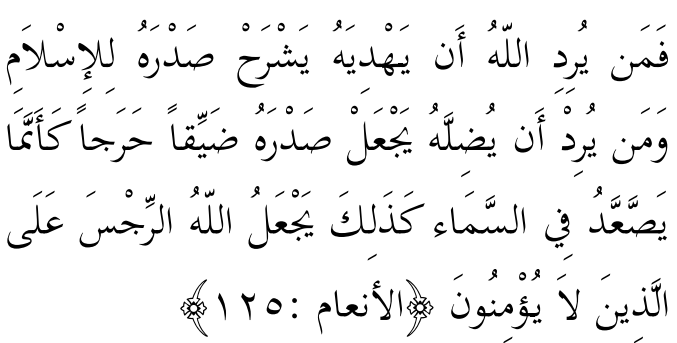

Barang siapa dikehendaki Allah akan mendapat hidayah (petunjuk), Dia akan membukakan dadanya untuk (menerima) Islam. Dan barang siapa dikehendaki-Nya menjadi sesat, Dia jadikan dadanya sempit dan sesak, seakan-akan dia (sedang) mendaki ke langit. Demikianlah Allah menimpakan siksa kepada orang-orang yang tidak beriman.

Oksigen akan berkurang pada lapisan udara yang tinggi. Semuanya itu telah dibuktikan oleh ilmu pengetahuan manusia, yaitu sejak manusia mampu menembus ruang angkasa dengan pesawat udara. Penelitian ilmu pengetahuan telah sampai pada kesimpulan bahwa di angkasa oksigen itu berkurang. Oleh sebab itu, manakala seorang penerbang meluncur di angkasa pada ketinggian 30.000 kaki, dadanya akan terasa sesak, sulit bernafas, dan karenanya si penerbang itu harus memakai oksigen buatan.

Itulah beberapa contoh penemuan ilmiah dalam rangka pembuktian terhadap kemukjizatan ilmiah al-Qur'an. Kemukjizatan ilmiah itu sendiri pada hakikatnya terletak pada dorongan al-Qur'an kepada umatnya untuk berfikir dan meneliti. Sejalan dengan itu, Allah telah membukakan pintu ilmu pe-ngetahuan supaya mereka memasuki gerbang ilmu melalui membaca, meneliti dan menerapkannya dalam kehidupan sehari-hari sebagai usaha membumikan konsep al-Qur'an.

\section{Pemecahan Isu-isu Kontem- porer}

Manusia sebagai makhluk sosial sudah jelas mengalami berbagai persoalan, dimana persoalan tersebut belum terjadi di zaman Rasul atau pada masamasa sebelumnya. Namun demikaian, pedoman untuk menye-lesaikannya tetap mengacu kepada al-Qur'an.

Di antara persoalan yang terjadi, misalnya dalam kasus Indonesia misalnya konflik antar etnik, antar kampong, antar suku, bahkan antar agama dan sebagainya. Penyebab konflik mungkin bermacam-macam, di antaranya saling mengejek, ada pihak yang buruk sangka, dan lain-lain. AlQur'an telah memberikan solusi sebagaimana frman-Nya :

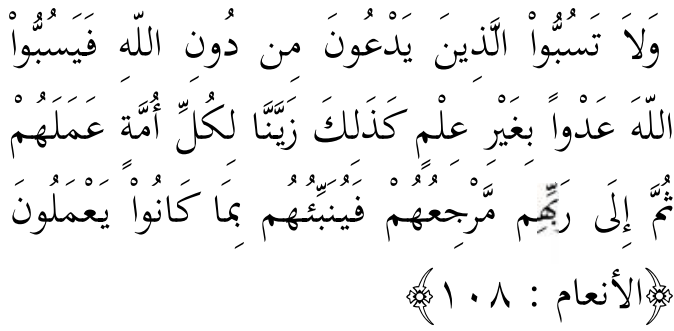

Dan janganlah kamu memaki sembahan-sembahan yang mereka sembah selain Allah, karena mereka nanti akan memaki Allah dengan melampaui batas tanpa pengetahuan. Demikianlah Kami jadikan setiap umat menganggap baik pekerjaan mereka. Kemudian kepada Tuhan merekalah kembali mereka, lalu Dia memberitakan kepada mereka apa yang dahulu mereka kerjakan. (Q.S. al-An'an (6): 108).

Begitu juga firman-Nya : 


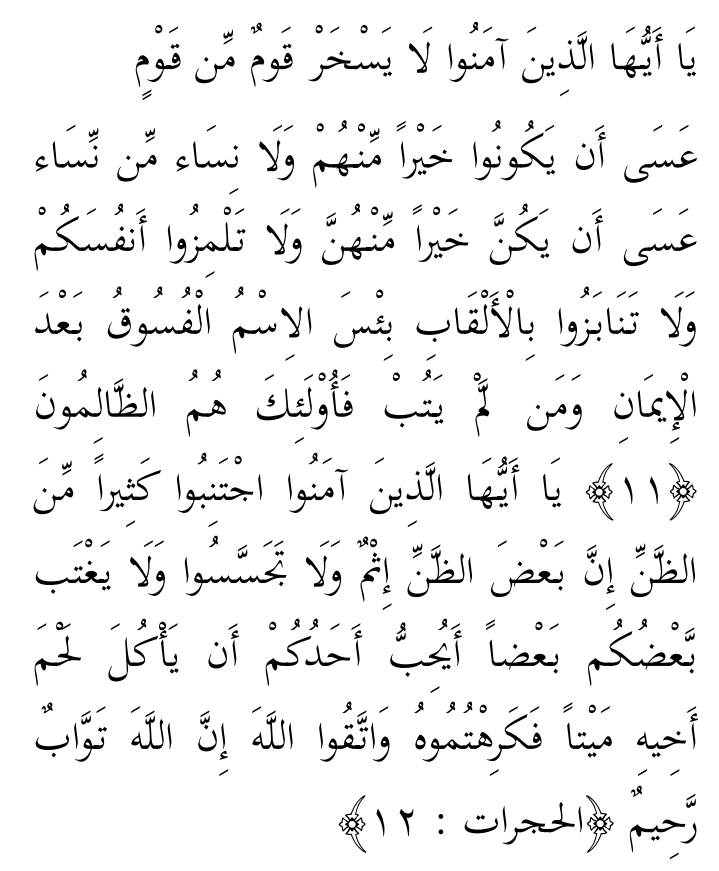

Hai orang-orang yang beriman janganlah suatu kaum mengolok-lok kaum yang lain (karena) boleh jadi mereka (yang diolok-olok) lebih baik dari mereka (yang mengolok-olok) dan jangan pula wanita-wanita (mengolokolok) wanita-wanita lain (karena) boleh jadi wanita-wanita (yang diperolok-olokkan) lebih baiko dari wanita (yang mengolok-olok) dan janganlah kamu mencela dirimu sendiri dan janganlah kamu panggil memanggil dengan gelar-gelar yang buruk. Seburuk-buruk panggilan ialah (panggilan) yang buruk sesudah iman dan barangsiapa yang tidak bertaubat, maka mereka itulah orang-orang yang zalim. Hai orang-orang yang beriman, jauhilah kebanyakan dari prasangka, sesungguhnya sebagian prasangka itu adalah dosa dan janganlah kamu mencari-cari kesalahan orang lain dan janganlah sebahagian kamu menggunjing sebahagian yang lain. Sukakah salah seorang di antara kamu memakan daging saudaranya yang sudah mati? Maka tentulah kamu merasa jijik kepadanya. Dan bertakwalah kepada Allah. Sesungguhnya Allah Maha Penerima taubat lagi Maha Penyayang. (Q. S. alHujurat,66 : 11-12)

Kemudian dalam masalah dekadensi moral yang terjadi, misalnya pelecehan seksual, bahkan terjadi pada anak-anak di bawah umur, al-Qur'an telah menggariskan al-Tahrim (66): 6 :

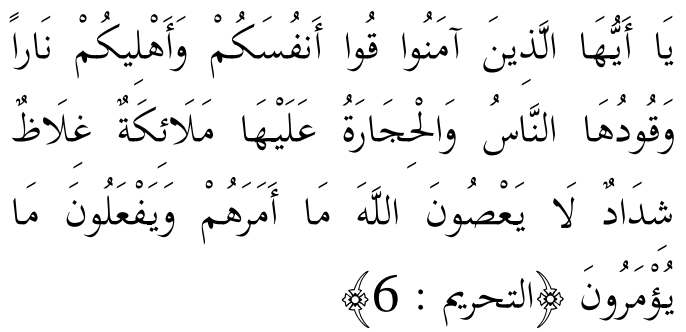

Kemudian firman-Nya dalam Surat Luqman (31) : 13 :

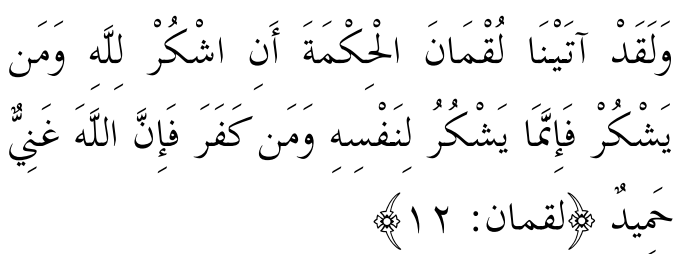

\section{MANHAJ MENAFSIRKAN AL- QUR'AN}

Untuk pemahaman yang tepat, ada beberapa hal yang mesti diperhatikan atau dipedomani, yang dapat dikatakan sebagai manhaj atau jalan untuk memahami al-Qur'an. Adapun manhaj tersebut, antara lain:

Pertama, kaidah bahasa Arab, hal ini karena al-Qur'an diturunkan Allah dalam bahasa Arab. Kaidah bahasa Arab itu meliputi minimal tiga aspek, yaitu kaidah nahwu, sharf, dan balaghah. Aspek nahwu berkaitan dengan fungsi kata dalam kalimat. Bila salah meletakkan fungsi suatu kata dalam kalimat, maka akan salah pula pemahaman kita terhadap kalimat itu. Misalnya firman Allah " Innamâ yakhsya Allâh min 'ibâdihi al- 
'ulamâ'" ( Sesungguhnya yang takut kepada Allah di antara hamba-hambaNya adalah 'ulama). Dalam ayat di atas, Allah berfungsi sebagai obyek, sedangkan al-'ulama sebagai subyek. Akan tetapi, kalau salah memfungsikan, dalam arti Allah difungsikan sebagai subyek (fâ'il), sementara al-'ulama sebagai obyek (maf' ûl bih), maka maksud ayat adalah "sesungguhnya hanya Allah-lah yang takut kepada para ulama di antara hamba-hamba-Nya". Bila begitu pemahamannya, maka jelas suatu kekeliruan. Aspek sharf adalah hal-hal yang berhubungan dengan perobahan bentuk kata. Dalam bahasa Arab, perobahan kata, baik berupa penambahan huruf, pengurangan, dan pertukaran letak huruf, berpengaruh kepada makna kata tersebut. Maka untuk memahami ayat al-Qur'an dengan tepat, seseorang mesti mengetahui perobahan tersebut. Sedangkan balaghah adalah aspek yang berhubungan dengan ketinggian sastra al-Qur'an, sehingga menarik, bahkan mengandung keindahan dalam susunan dan gaya bahasanya. Jadi, penguasaan bahasa Arab yang baik sangat diperlukan bilamana seseorang memahami al-Qur'an dengan benar, apalagi kalau ingin lebih dari itu, yaitu menafsirkannya. Adalah sangat naif bila seseorang menggali kandungan alQur'an secara langsung, padahal ia sendiri tidak mengerti bahasa Arab.

Kedua, prinsip bahwa sebagian ayat al-Qur'an menafsirkan sebagian yang lain ( $a l-Q u r ' a n$ yufassiru ba'dhuhu ba'dhan ). Suatu masalah dikemukakan secara global pada suatu ayat, sementara pada ayat lain dijelaskan secara rinci. Atau suatu ayat berbicara tentang sesuatu secara muthlaq, pada hal di ayat lain berbicara mengenai masalah yang sama secara muqayyad. Begitu seterusnya. Oleh sebab itu, suatu ayat yang berbicara tentang suatu masalah tidak bisa dipahami secara final (muthlak), tanpa menghubungkannya dengan ayat lain yang berbicara tentang masalah yang sama. Misalnya ayat 43 dari surat al-Nisa' “ $y \hat{a}$ ayyuhâ alladzina âmanû la taqrabû al-shalâta wa antum sukara hatta ta'lamu mâ taqûlûn" ( Wahai orang-orang yang beriman ! Janganlah kamu mendekati shalat, ketika kamu dalam keadaan mabuk, sampai kamu sadar apa yang kamu ucapkan). Bila ayat ini dipahami secara parsial saja, tanpa menghubungkannya dengan ayat lain, akan dipahami bahwa meminum minuman yang memabukkan hanya diharamkan di waktu akan shalat saja, pada hal, di ayat 90 surat al-Maidah yang turun setelah ayat 43 surat alNisa' di atas ditegaskan keharaman minuman keras secara total "Wahai orang-orang yang beriman! Sesungguhnya minuman keras, berjudi, ( berkurban untuk) berhala, dan mengundi nasib dengan anak panah, adalah perbuatan keji dan termasuk perbuatan setan. Maka jauhilah (perbuatan-perbuatan) itu agar kamu beruntung".

Ketiga, memperhatikan munâsabah, dalam hal ini sebagai salah satu bagian yang tidak kalah pentingnya dari 'ulum al-Qur'an. Secara etimologi, munâsabah artinya saling kedekatan makna, saling berhubungan atau berkorelasi. Sedangkan secara terminologis, artinya adanya satu bentuk hubungan antara satu surat dengan berikutnya, hubungan antara satu ayat dengan berikutnya, begitu pun adanya hubungan antara satu kalimat dengan 
berikutnya pada ayat yang sama. Munâsabah antara satu surat dengan surat sebelumnya antara lain berfungsi untuk menjelaskan kandungan surat sebelumnya, baik dalam bentuk merinci apa yang dijelaskan secara global sebelumnya, menjelaskan maksudnya, ataupun menguraikan apa yang dijelaskan secara singkat sebelumnya. Misalnya dalam mengungkap hubungan antara surat alFâtihah dengan surat al-Baqarah. Akhir surat al-Fâtihah berbicara tentang permohonan kepada Allah untuk ditunjuki "jalan yang lurus" (alshirâth al-mustaqîm), sementara di awal surat al-Baqarah Allah informasikan bahwa al-kitâb (dalam hal ini maksunya al-Quran) adalah petunjuk bagi orang-orang bertaqwa. Jadi al-shirâth al-mustaqîm (jalan yang lurus) itu adalah al-Qur'an alKarim.

Selanjutnya munâsabah (hubungan) antara satu ayat dengan sebelumnya, di antaranya ada yang bersifat jelas dan ada pula yang bersifat tidak jelas. Munâsabah yang bersifat jelas terjadi karena adanya suatu masalah yang tidak tuntas dijelaskan dalam satu ayat, kemudian uraiannya dituntaskan dalam ayat-ayat berikutnya, baik itu dalam bentuk penekanan (ta'kîd) dan penafsiran ataupun keberpalingan dan penguatan (tasydîd). Misalnya hubungan antara ayat ke 2 dan ke 3 dari surat alBaqarah. Ayat ke 2 "dzâlika al-kitâbu la raiba fîh hudan li al-muttaqîn" (Kitab (al-Qur'an) ini tidak ada keraguan padanya; petunjuk bagi mereka yang bertaqwa). Dalam ayat ke 2 ini, Allah informasikan bahwa alQur'an itu petunjuk untuk mereka yang bertaqwa. Siapa saja yang tergolong kepada orang-orang yang bertaqwa itu dijelaskan Allah dalam ayat berikutnya : "al-dzina yu'minuna bi al-ghaib, wa yuqimuna al-shalata wa mimma razaqnahum yunfiqun". Identitas orang-orang bertaqwa itu adalah beriman kepada yang ghaib, menegakkan shalat, dan menginfakkan sebagian rezki yang diberikan Allah kepada mereka.

Hubungan antara satu kalimat dengan kalimat sebelumnya juga dalam rangka menjelaskan suatu masalah yang telah disebutkan pada ayat sebelumnya, namun belum tuntas. Misalnya surat al-Baqarah ayat 189 "yas-alûnaka 'an al-ahillah, qul hia mawâgîtu li al-nâs wa al-haj" ( Mereka bertanya kepadamu (Muhammad) tentang bulan sabit. Katakanlah, "itu adalah (penunjuk) waktu bagi manusia dan (ibadah) haji ). Jadi, pada kalimat pertama informasi kalau ada pertanyaan umat kepada Nabi tentang bulan sabit, maka pada kalimat kedua terdapat jawaban yang bisa dikemukakan Nabi tentang manfaat bulan sabit itu, yaitu sebagai penunjuk waktu bagi manusia dan pedoman untuk melaksanakan ibadah haji.

Berangkat dari adanya munâsabah seperti dijelaskan di atas, maka susunan surat dan ayat dalam mushaf al-Qur'an seperti keadaannya sekarang, di mana tidak tersusun berdasarkan kronologis turunnya itu berdasarkan tauqifiy Tauqîfiy artinya, bahwa susunan ayat-ayat al-Qur'an itu ditentukan langsung oleh Allah dengan memberikan bimbingan kepada Nabi Muhammad Saw. melalui Malaikat Jibril. Namun demikian, khusus berkenaan dengan susunan surat-surat, masih terdapat perbedaan pendapat di kalangan para ulama. Bahkan juga, di 
antara kritik yang dilontarkan khususnya oleh sebagian orientalisterhadap al-Qur'an adalah berkenaan dengan susunan ayat-ayat dan suratsuratnya yang dianggap tidak sistematis. Tidak jarang ditemukan uraiannya tentang suatu masalah serta merta berpindah ke uraian masalah lain, sedangkan masalah sebelumnya itu belum tuntas diuraikan. Di samping itu, banyak pula suatu uraian muncul tanpa ada kaitannya dengan uraian sebelumnya. Keyakinan akan ke tauqîfi-an sistematika al-Qur'an itulah yang memotivasi para ulama untuk berusaha menangkap hikmah dan rahasia yang ada di balik susunan tersebut. Dalam upaya menangkap hikmah dan rahasia di balik sistematika susunan ayat dan surat alQur'an itulah para ulama kemudian mengembangkan ilmu munâsabah tersebut. Sebagai salah satu cabang dari ilmu-ilmu al-Qur'an, ilmu munâsabah kurang mendapat per-hatian dibanding cabang-cabang ilmu al-Qur'an lainnya. Hal itu terbukti dengan sedikitnya kecenderungan para mufassir dalam menjelaskan aspek-aspek munâsabah dalam karya-karya tafsir mereka. Pada hal, ilmu munâsabah sesungguhnya mempunyai kedudukan cukup penting dalam bingkai ilmu-ilmu al-Qur'an,

\section{DAFTAR KEPUSTAKAAN}

Al-Qur'an al-Karim

Badruddin Muhammad bin Abdullah al-Zakraksyi, al-Burhan Fi 'Ulum al-Qur'an, Kairo: Isa al-Babi al-Halabi, 1972

Dep. Agama RI, al-Qur;an dan Terjemahnya, Madinah: Mujamma' al-Malik Fahd li karena peranannya yang demikian besar dan penting untuk membantu memahami maksud ayat-ayat alQur'an.

\section{KESIMPULAN}

1. Al-Qur'an sebagai petunjuk (pedoman) mesti dipahami dan ditafsirkan dan diaktualkan sesuai dengan konteks kekinian.

2. Ulum al-Qur'an sangat urgen posisinya untuk memahami dan menafsirkan al-Qur'an.

3. Dalam hal pemahaman dan penafsiran al-Qur'an, ada tiga hal yang saling bersinerji, yaitu :

a. Kaidah-kaidah bahasa Arab, karena al-Qur'an diturunkan dalam bahasa Arab.

b. Suatu ayat menafsirkan ayat lain, hal itu karena adanya ayatayat yang mujmal yang terdapat rinciannya di ayat lain.

c. Prinsip asbab al-nuzul dan munasabah, yaitu adanya korelasi (keterkaiatan) antar kalimat, antar ayat, dan antar surat dalam al-Qur'an.

Thiba'at al-Mushhaf alSyarif, $1415 \mathrm{H}$

Kementerian Agama RI, Al-Qur'an dan Isu-isu Kontemporer I, Jakarta: Lajnah Pentashhihan Al-Qur'an, 2012

Manna' Khalil al-Qaththan, Mabahits Fi 'Ulum al- 
Qur'an, Beirut: Muassasah al-Risalah, 1973

Muhammad Abd. Al- 'Azhim alZarqani, Manahil al- 'Irfan $F i$ 'Ulum al-Qur'an, Beirut: Dar al-Fikr, 1988
Muhammad Quraish Shihab, Membumikan al-Qur'an, Bandung: Mizan, 1993

Rusydi AM, Ulum Al-Qur'an I, Padang: IAIN IB Press, 1999 